JERZY BABIAK

Poznań

\title{
Zróżnicowanie poziomu życia mieszkańców Unii Europejskiej
}

\begin{abstract}
Wstęp
Świat jest pełen sprzeczności. Zróżnicowanie występuje w wielu obszarach i na różnych poziomach. Jednym z tych wymiarów jest jakość życia przejawiająca się w ubóstwie i głodzie na jednym biegunie i zamożności na jego drugim krańcu.

Jest sprawą bezdyskusyjna, iż głód i niedożywienie silnie skorelowane z ubóstwem, w głównej mierze dotyczą przede wszystkim tzw. państw „Trzeciego Świata”. Wedle szacunków Organizacji Narodów Zjednoczonych do spraw Wyżywienia i Rolnictwa (ang. Food and Agriculture Organization of the United Nations, FAO) ogólna liczba osób niedożywionych zmniejszyła się z $868 \mathrm{mln}$ w latach 2010-2012 do $842 \mathrm{mln}$ obecnie (2011-2013). W porównaniu do szacunków z lat 1990-1992 odsetek niedożywianych spadł o $17 \%$. Mimo tych widocznych pozytywnych zmian, na świecie nadal co ósma osoba cierpi z powodu chronicznego głodu lub nie otrzymuje wystarczającej porcji pożywienia by wieść aktywne życie (Food and Agriculture Organization, s. 8). W ostatnich latach odsetek osób zagrożonych ubóstwem i wykluczeniem społecznym zaczął rosnąć także w regionach wysoko rozwiniętych, w tym również w UE. Problem ubóstwa wiąże się ponadto $\mathrm{z}$ kwestiami demograficznymi. W tym kontekście niepokojącym jest zjawisko starzejącej się populacji krajów zachodnioeuropejskich, co jest o tyle istotne, iż osoby starsze są jedną z grup szczególnie zagrożonych ubóstwem, ich liczba zaś ustawicznie rośnie. Mając na uwadze wagę problemu, walkę z ubóstwem Komisja Europejska uznała za jeden z pięciu podstawowych kierunków wytyczonych w dokumencie strategicznym Europa 2020.
\end{abstract}

\section{Problemy terminologiczne - mierniki poziomu życia}

Poziom życia jest kategorią niejednoznaczną, stąd też próbując ją określić można powołać się na różne mierniki z nią związane. Obok czysto ekonomicznych wskaźników takich jak: Miernik Dobrobytu Ekonomicznego (ang. Measure of Economic Welfare, MEW) czy też jego zmodyfikowana wersja - Miernik Krajowego Dobrobytu (ang. Net National Welfare, NNW) są też takie, które uwzględniają subiektywne odczucia respondentów.

Dane na temat ubóstwa, warunków, jakości życia, dochodów czy też deprywacji materialnej Unia Europejska zbiera w ramach różnych instrumentów i badań. Jednym $\mathrm{z}$ nich jest Europejskie badanie warunków życia ludności (ang. The European Union 
Statistics on Income and Living Conditions, EU-SILC), które stanowi punkt odniesienia dla statystyk dotyczących dystrybucji dochodów i integracji społecznej w UE ${ }^{1}$. Badanie skoncentrowane jest na dochodach, dostarcza jednak także informacji na temat wykluczenia społecznego, warunków mieszkaniowych, pracy, edukacji i ochrony zdrowia. Statystyki te obejmują zarówno obiektywne, jak i subiektywne aspekty podejmowanych tematów i są wykorzystywane do monitorowania Strategii Europa 2020, w szczególności w obszarze redukcji ubóstwa (Eurostat, 2013a). Pierwsze, nieformalne badanie EU-SILC zostało przeprowadzone w 2003 r. i obejmowało sześć państw członkowskich (Austrię, Belgię, Danię, Grecję, Irlandię, Luksemburg) oraz Norwegię. Obecnie biorą w nim udział wszystkie państwa członkowskie UE-28 oraz Islandia, Norwegia, Szwajcaria i Turcja (Eurostat, 2013b).

Unia Europejska w swoich strukturach wyodrębniła ponadto jednostkę monitorująca warunki życia obywateli. Eurofound, czyli Europejska Fundacja na rzecz Warunków Życia i Pracy (ang. The European Foundation for the Improvement of Living and Working Conditions) w ramach swojej działalności prowadzi ogólnoeuropejskie badania jakości życia (ang. European Quality of Life Survey, EQLS). Pierwsze badanie zostało przeprowadzone w $2003 \mathrm{r}$. i od tego momentu odbywa się co 4 lata $^{2}$. W EQLS nie tylko analizuje się obiektywne okoliczności życia mieszkańców Europy, ale bierze się także pod uwagę subiektywne ich odczucia. Badanie uwzględnia kilka obszarów, m.in. zatrudnienie i równowagę między życiem zawodowym i prywatnym, życie rodzinne i społeczne, środowisko rodzinne i lokalne, jakość społeczeństwa, wykluczenie społeczne oraz zaangażowanie społeczne, standard życia i deprywacji, czy wreszcie subiektywne odczucia (Eurofund).

Poziom jakości życia monitoruje także międzynarodowa organizacja HelpAge (ang. HelpAge International $)^{3}$, której badania koncentrują się na osobach starszych. W 2013 r. przygotowała ona raport, w którym prezentuje nowe narzędzie - Global AgeWatch Index.

\section{Poziom życia w państwach UE}

Poziom życia ściśle powiązany jest z dochodami. Jednym ze wskaźników monitorujących zróżnicowanie w dochodach jest współczynnik Giniego. W 2011 r. najwyższe wartości przyjął dla Łotwy $(35,4)$, Bułgarii $(35,0)$, Hiszpanii $(34,5)$, Portugalii $(34,2)$, Grecji $(33,5)$. Najmniejsze zróżnicowanie występuje w Słowenii $(23,8)$, Szwecji $(24,4)$,

\footnotetext{
1 Oprócz 28 państw członkowskich Unii Europejskiej, statystykami objęta jest Islandia, Norwegia, Szwajcaria i Turcja.

${ }_{2}$ W pierwszym badaniu EQLS w 2003 r. udział wzięło 28 państw: 27 państw członkowskich UE i Turcja. Drugim badaniem EQLS w latach 2007-2008 objętych zostało 31 państw: 27 państw członkowskich UE, Chorwacja, Była Jugosłowiańska Republika Macedonii, Turcja i Norwegia. W trzecim EQLS w latach 2011-2012 uczestniczyły 34 państwa: 27 państw członkowskich UE i Chorwacja, Islandia, Była Jugosłowiańska Republika Macedonii, Czarnogóra, Serbia, Turcja i Kosowo.

${ }^{3}$ HelpAge International powstał w 1983 r. Został założony przez pięć organizacji z Kanady, Kolumbii, Kenii, Indii i Wielkiej Brytanii.
} 
Czechach $(25,2)$, na Słowacji $(25,7)$, w Finlandii $(25,8)$ i Holandii $(25,8)$. Dla Polski wskaźnik przyjmuje wartość 31,1 i wypada nieznacznie wyżej niż dla całej UE $(30,7)$.

\section{Wykres 1. Wspólczynnik Giniego ekwiwalentnych dochodów do dyspozycji w 2011 r. $^{4}$}

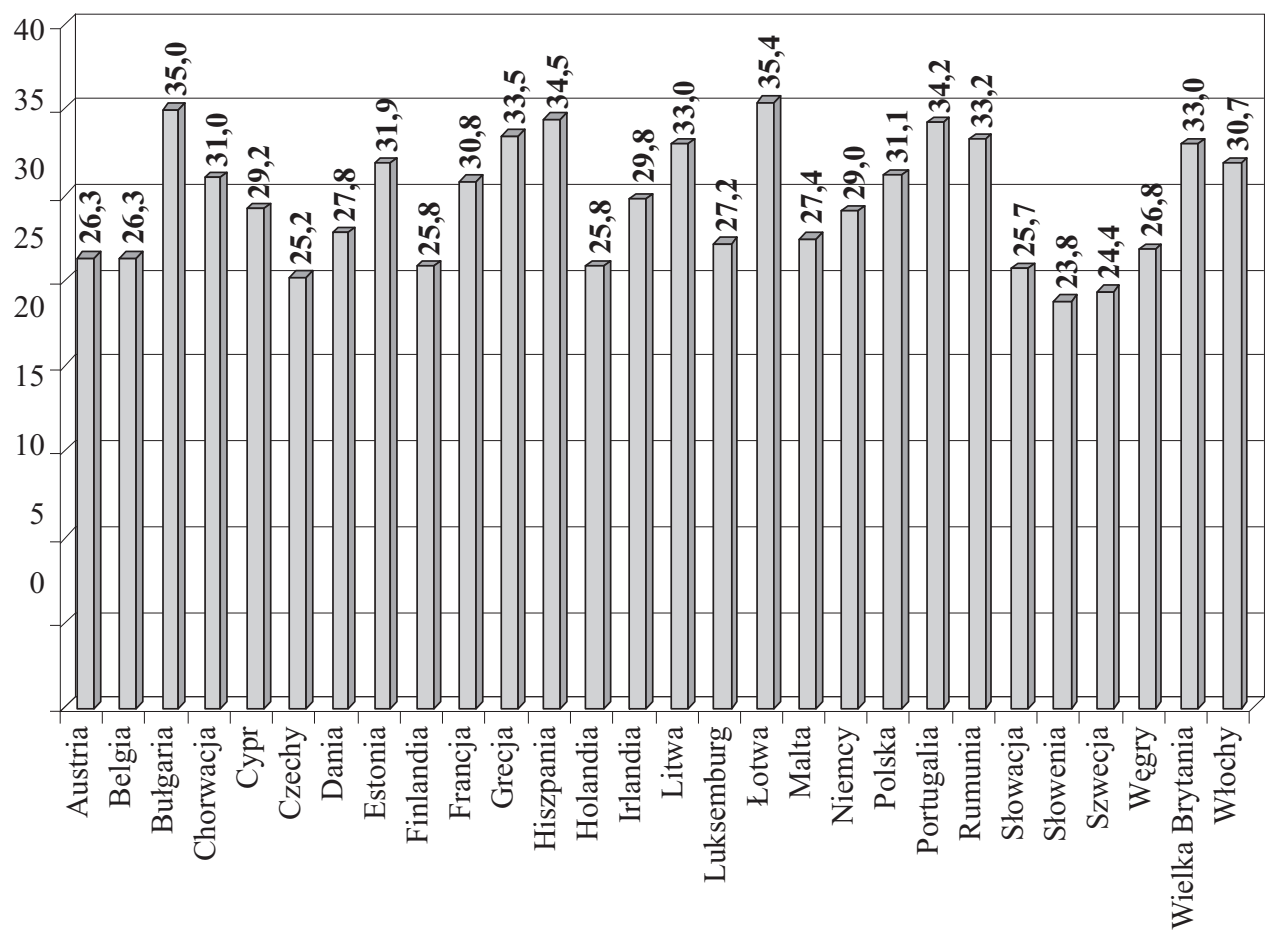

Źródło: Eurostat, http://epp.eurostat.ec.europa.eu/portal/page/portal/income_social_inclusion_living_conditions/ data/main_tables, dostęp 29.10.2013.

Dane na temat zróżnicowania dochodowego w państwie, częściowo znalazły swoje odzwierciedlenie w opiniach respondentów uzyskanych w ramach najnowszego EQLS z 2012 r. ${ }^{5}$ Wynika z nich, iż najwięcej osób swoją sytuację finansową w porównaniu do większości w państwie ocenia jako dużo gorszą lub nieznacznie gorszą w Bułgarii (36\%) i Grecji (33\%). W przypadku tych dwóch państw odczucia obywateli pokrywają się z wysokimi wskaźnikami zróżnicowania dochodowego w ich państwach. Brak tej zbieżności zachodzi natomiast w przypadku Słowacji i Słowenii. Są to jedne z państw o najniższym zróżnicowaniu dochodowym i zarazem państwa z wysokim odsetkiem

${ }^{4}$ Współczynnik Giniego jest to miara nierówności rozkładu dochodów. Przybiera ona wartość między 0 a 1 (lub jeśli przemnożymy przez 100, między 0 a 100). Wartość 0 (rozkład jednorodny), oznaczałaby, że wszystkie osoby mają ten sam dochód, natomiast wartość 100 wskaźnik przyjąłby, gdyby wszystkie osoby poza jedną miały dochód zerowy. Stąd też, im wyższa jest wartość wskaźnika, tym większy jest stopień koncentracji dochodów i większe jest ich zróżnicowanie.

5 Badanie zostało przeprowadzone wśród osób od 18 roku życia, od września 2011 do lutego 2012 r. W zależności od wielkości państwa członkowskiego populacja przebadanych liczyła od 1 tys. do 3 tys. osób. 
osób oceniających swoją sytuację finansową jako dużo lub nieznacznie gorszą od innych (Słowacja - 34\% i Słowenia 31\%). Podobnie Węgrzy odnoszą się do swojej sytuacji (31\% - dużo lub nieznacznie gorsza), przy zróżnicowaniu na poziomie 26,8 , czyli poniżej wielkości dla UE.

Wykres 2. Sytuacja finansowa gospodarstw domowych w porównaniu do większości ludzi w państwie

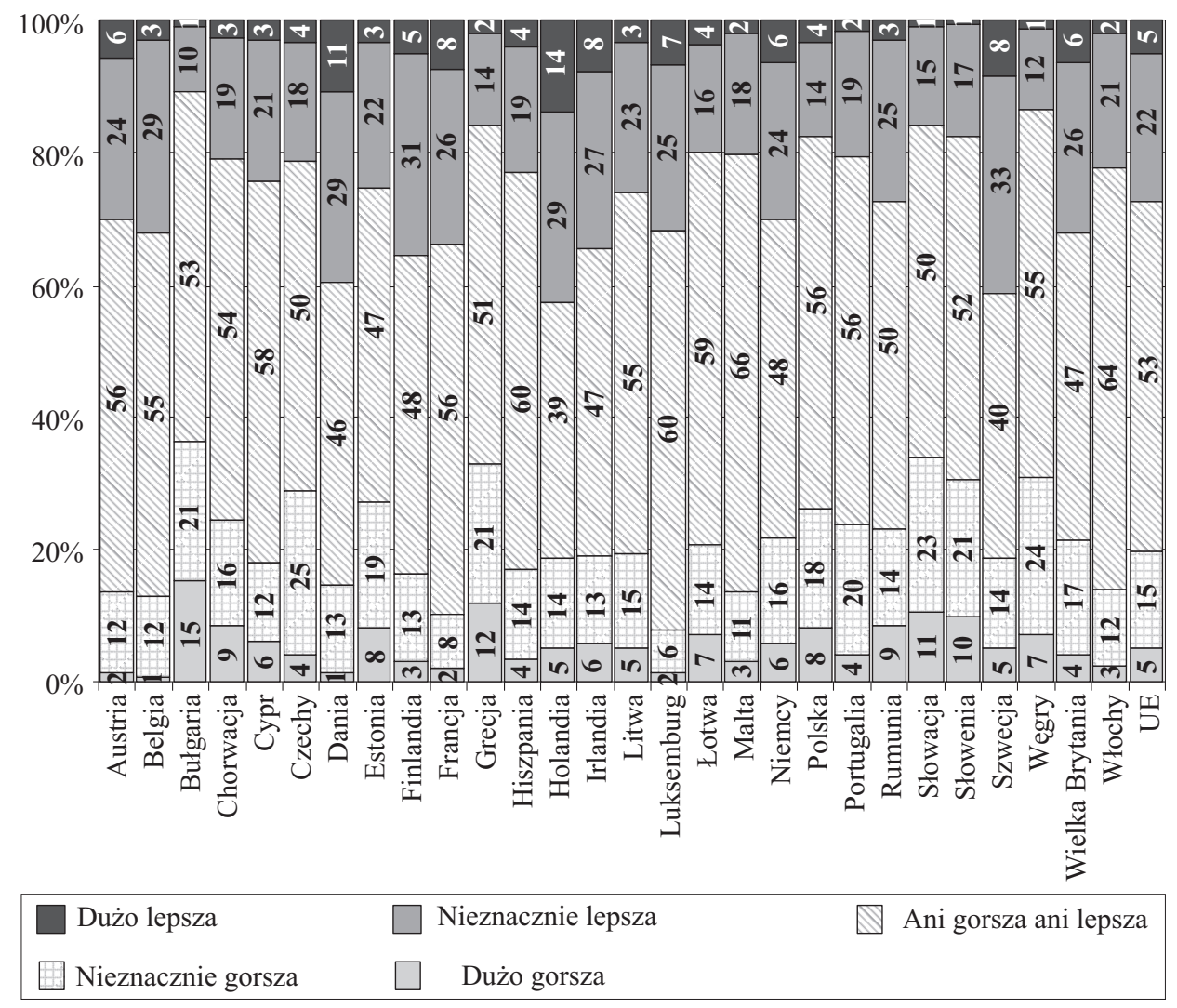

Źródło: Eurofund, http://www.eurofound.europa.eu/surveys/smt/3eqls/index.EF.php?locale=EN, dostęp 29.10.2013.

Jakości życia osób w wieku 60 lat i więcej dotyczy natomiast wskaźnik Global AgeWatch Index (GAWI). Na GAWI składa się 13 wskaźników wyodrębnionych w czterech dziedzinach:

- bezpieczeństwo dochodowe - dotyczy dostępności do wystarczającej wysokości dochodu, którym osoba starsza może dysponować w sposób niezależny; obejmuje następujące wskaźniki:

- stosunek wysokości renty/emerytury do poziomu kosztów utrzymania,

- wskaźnik ubóstwa w starszym wieku,

- relatywny dobrobyt osób starszych,

- PKB per capita;

- status zdrowia - odnosi się do fizycznej i psychicznej kondycji osób 60+; wskaźnik zbudowano w oparciu o: 
- oczekiwaną długość życia wśród 60-latków,

- oczekiwaną długość życia w zdrowiu wśród 60-latków,

- psychiczne samopoczucie;

- zatrudnienie i edukacja uwzględnia:

- zatrudnienie ludzi starszych,

- status edukacyjny ludzi starszych;

- aktywizujące środowisko - wskaźnik ten jest ściśle związany ze spójnością i integracją społeczną i opiera się na subiektywnych opiniach osób 50+ przebadanych przez Gallup WorldWide poll, uwzględnia:

- więzi społeczne,

- bezpieczeństwo fizyczne,

- wolności obywatelskie,

- dostępność do transportu publicznego (HelpAge International, s. 13-14).

Z rankingu wynika, iż osobom 60+ najlepiej żyje się w regionie nordyckim, Europie Zachodniej, Ameryce Północnej oraz niektórych państwach Azji Wschodniej i Ameryki Łacińskiej. W klasyfikacji generalnej na 91 państw uwzględnionych w zestawieniu, w pierwszej dwudziestce znalazło się aż 11 państw z Unii Europejskiej. Polska uplasowała się na 62 pozycji. Biorąc natomiast pod uwagę wyłącznie państwa członkowskie UE Polska zajmuje miejsce ostatnie. Najlepiej osobom 60+ żyje się w Szwecji, Niemczech oraz Holandii, które uzyskały blisko 90 punktów. Wszystkie trzy państwa znalazły się także w pierwszej dziesiątce w każdym z czterech obszarów. Ponadto Szwecja i Niemcy znalazły się także w pierwszej dziesiątce klasyfikacji uwzględniającej wszystkie 91 państw i to we wszystkich czterech obszarach.

Tabela 1

Global AgeWatch Index w państwach Unii Europejskiej

\begin{tabular}{|c|l|c|}
\hline $\begin{array}{c}\text { Pozycja } \\
\text { w rankingu }\end{array}$ & \multicolumn{1}{|c|}{ Państwo } & $\begin{array}{c}\text { Wartość* } \\
\text { GAWI ogólem }\end{array}$ \\
\hline 1. & Szwecja & 89,9 \\
\hline 2. & Niemcy & 89,3 \\
\hline 3. & Holandia & 88,2 \\
\hline 4. & Austria & 79,8 \\
\hline 5. & Irlandia & 79,5 \\
\hline 6. & Wielka Brytania & 78,7 \\
\hline 7. & Finlandia & 77,1 \\
\hline 8. & Luksemburg & 76,7 \\
\hline 9. & Dania & 75,9 \\
\hline 10. & Francja & 75,0 \\
\hline 11. & Słowenia & 70,5 \\
\hline 12. & Hiszpania & 67,6 \\
\hline 13. & Belgia & 67,0 \\
\hline 14. & Czechy & 62,5 \\
\hline
\end{tabular}

\begin{tabular}{|c|l|c|}
\hline $\begin{array}{c}\text { Pozycja } \\
\text { w rankingu }\end{array}$ & \multicolumn{1}{|c|}{ Państwo } & $\begin{array}{c}\text { Wartość* } \\
\text { GAWI ogółem }\end{array}$ \\
\hline 15. & Włochy & 61,4 \\
\hline 16. & Estonia & 60,2 \\
\hline 17. & Portugalia & 57,8 \\
\hline 18. & Malta & 55,8 \\
\hline 19. & Węgry & 54,7 \\
\hline 20. & Chorwacja & 53,1 \\
\hline 21. & Lotwa & 52,5 \\
\hline 22. & Bułgaria & 51,7 \\
\hline 23. & Rumunia & 51,4 \\
\hline 24. & Słowacja & 51,2 \\
\hline 25. & Litwa & 50,7 \\
\hline 26. & Cypr & 48,2 \\
\hline 27. & Grecja & 47,4 \\
\hline $\mathbf{2 8 .}$ & Polska & $\mathbf{4 5 , 9}$ \\
\hline
\end{tabular}

* Autorzy przyjęli liczbę 100 za warunki idealne. Poszczególne liczby zawarte w kolumnie wskazują w jakim procencie dane państwo zbliżone jest do sytuacji idealnej.

Źródło: Zestawienie własne na podstawie HelpAge International (2013), Global AgeWatch Index 2013. Insight Report, s. 39. 
Różnica między Polską a Szwecją zajmującą pierwszą pozycję w zestawieniu wynosi aż 44 punkty. Biorąc pod uwagę poszczególne wskaźniki, okazuje się, iż Polska najlepiej wypadła jeżeli chodzi o bezpieczeństwo dochodowe, zajmując 14 miejsce, osiaggając wartość 82,6 punktów w przedziale $22,0-98,2$. Nieznacznie gorzej, bo na 17 miejscu znalazła się w obszarze: „aktywizujące środowisko” (wartość 64,8; przedział 51,6-85,6). W rankingu wskaźnika dotyczącego zatrudnienia i edukacji zajęła 23 miejsce osiaggając wartość 38,8; (przedział 24,4-74,3). Ostatnie miejsce zajęła natomiast w obszarze zdrowotnym uzyskując 23,9 punktów (najwięcej Niemcy - 75,2).

\section{Poziom zagrożenia ubóstwem i wykluczeniem społecznym w UE}

O poziomie życia społeczeństwa i jego zróżnicowaniu dużo mówią wskaźniki zagrożenia ubóstwem lub wykluczeniem społecznym. Dane na ten temat stanowią element składowy statystyk zbieranych w ramach Europejskiego badania warunków życia ludności (EU-SILC).

Tabela 2

Ludność zagrożona ubóstwem i wykluczeniem spolecznym (\% z populacji)

\begin{tabular}{|c|c|c|c|c|c|c|c|c|}
\hline \multirow{2}{*}{ Państwo } & \multicolumn{8}{|c|}{ Rok } \\
\hline & 2005 & 2006 & 2007 & 2008 & 2009 & 2010 & 2011 & 2012 \\
\hline 1 & 2 & 3 & 4 & 5 & 6 & 7 & 8 & 9 \\
\hline UE 28 & - & - & - & - & - & 23,6 & 24,3 & $25,1^{\mathrm{s}}$ \\
\hline Austria & 16,8 & 17,8 & 16,7 & 18,6 & 1,07 & 16,6 & 16,9 & - \\
\hline Belgia & 22,6 & 21,5 & 21,6 & 20,8 & 20,2 & 20,8 & 21,0 & - \\
\hline Bułgaria & - & 61,3 & 60,7 & $44,8^{\mathrm{b}}$ & 46,2 & 49,2 & 49,1 & 49,3 \\
\hline Chorwacja & - & - & - & - & - & 31,3 & 32,7 & - \\
\hline Cypr & 25,3 & 25,4 & 25,2 & $23,3^{\mathrm{b}}$ & 23,5 & 24,6 & 24,6 & 27,1 \\
\hline Czechy & 19,6 & 18,0 & 15,8 & 15,3 & 14,0 & 14,4 & 15,3 & 15,4 \\
\hline Dania & 17,2 & 16,7 & 16,8 & 16,3 & 17,6 & 18,3 & 18,9 & 19,0 \\
\hline Estonia & 25,9 & 22,0 & 22,0 & 21,8 & 23,4 & 21,7 & 23,1 & 23,4 \\
\hline Finlandia & 17,2 & 17,1 & 17,4 & 17,4 & 16,9 & 16,9 & 17,9 & 17,2 \\
\hline Francja & 18,9 & 18,8 & 19,0 & $18,6^{\mathrm{b}}$ & 18,5 & 19,2 & 19,3 & 19,1 \\
\hline Grecja & 29,4 & 29,3 & 28,3 & 28,1 & 27,6 & 27,7 & 31,0 & 34,6 \\
\hline Hiszpania & 24,3 & 24,0 & 23,3 & 24,5 & 24,5 & 26,7 & 27,7 & 28,2 \\
\hline Holandia & 16,7 & 16,0 & 15,7 & 14,9 & 15,1 & 15,1 & 15,7 & 15,0 \\
\hline Irlandia & 25,0 & 23,3 & 23,1 & 23,7 & 25,7 & 27,3 & 29,4 & - \\
\hline Litwa & 41,0 & 35,9 & 28,7 & 27,6 & 29,5 & 33,4 & 33,1 & 32,5 \\
\hline Luksemburg & 17,3 & 16,5 & 15,9 & 15,5 & 17,8 & 17,1 & 16,8 & 18,4 \\
\hline Łotwa & 45,8 & 41,4 & 36,0 & $33,8^{\mathrm{b}}$ & 37,4 & 38,1 & $40,4^{\mathrm{b}}$ & 36,6 \\
\hline Malta & 20,2 & 19,1 & 19,4 & 19,6 & 20,2 & 20,3 & 21,4 & 22,2 \\
\hline
\end{tabular}




\begin{tabular}{||l|c|c|c|c|c|c|c|c||}
\hline \multicolumn{1}{|c|}{1} & 2 & 3 & 4 & 5 & 6 & 7 & 8 & 9 \\
\hline Niemcy & 18,4 & 20,2 & 20,6 & 20,1 & 20,0 & 19,7 & 19,9 & 19,6 \\
\hline Polska & 45,3 & 39,5 & 34,4 & $30,5^{\mathrm{b}}$ & 27,8 & 27,8 & 27,2 & 26,7 \\
\hline Portugalia & 26,1 & 25,0 & 25,0 & 26,0 & 24,9 & 25,3 & 24,4 & 25,3 \\
\hline Rumunia & - & - & 45,9 & 44,2 & 43,1 & 41,4 & 40,3 & 41,7 \\
\hline Słowacja & 32 & 26,7 & 21,3 & 20,6 & 19,6 & 20,6 & 20,6 & 20,5 \\
\hline Słowenia & 18,5 & 17,1 & 17,1 & 18,5 & 17,1 & 18,3 & 19,3 & 19,6 \\
\hline Szwecja & 14,4 & 16,3 & 13,9 & 14,9 & 15,9 & 15,0 & 16,1 & - \\
\hline Węgry & 32,1 & 31,4 & 29,4 & 28,2 & 29,6 & 29,9 & 31 & 32,4 \\
\hline Wielka Brytania & 24,8 & 23,7 & 22,6 & 23,2 & 22,0 & 23,2 & 22,7 & - \\
\hline Włochy & 25,0 & 25,9 & 26,0 & 25,3 & 24,7 & 24,5 & 28,2 & $30,4^{\mathrm{t}}$ \\
\hline \hline
\end{tabular}

$-=$ brak danych;

$\mathrm{s}=$ szacunki Eurostatu;

$\mathrm{b}=$ przerwa $\mathrm{w}$ serii danych;

$\mathrm{t}=$ tymczasowy.

Źródlo: Eurostat, http://epp.eurostat.ec.europa.eu/portal/page/portal/income_social_inclusion_living_conditions/data/main_tables, dostęp 29.10.2013.

Jak wynika z tabeli 2. w latach 2005-2012 wartości wskaźnika zagrożenia ubóstwem lub wykluczeniem społecznym podlegały okresowym zmianom. Większość państw najniższą jego wartość osiągnęła w latach 2008-2009, po czym zaczęła ona stopniowo wzrastać. Największy przyrost w stosunku do roku 2008 zanotowano na Litwie (4,9 pkt proc.), w Bułgarii (4,5 pkt proc.), na Węgrzech (4,2 pkt proc.) i Cyprze ( 3,8 pkt proc.). W Irlandii i Hiszpanii najniższe wartości wskaźnika zaobserwowano w 2007 r. i od tego okresu wskaźnik wzrósł odpowiednio o 6,3 pkt proc. i 4,9 pkt proc. Jeszcze większy przyrost i to w krótszym czasie (2009-2012) zanotowano w Grecji (7,0 pkt proc.) i Włoszech (5,7 pkt proc.). Jego wartość wzrosła także dla całej Unii Europejskiej (UE-28) z 23,6\% w 2010 r. do 25,1\% w r. 2012. Oznacza to, że w 2010 r. w UE żyło ok. 115 mln ludzi zagrożonych ubóstwem lub wykluczeniem społecznym (Eurostat news release, 21/2012), rok później zaś ich liczba osiagnęła już pułap $119,6 \mathrm{mln}$ (Eurostat news release, 171/2012). Pomimo dostrzegalnej w ostatnich latach poprawy, czyli spadku wskaźnika, w kilku państwach jego wartość nadal pozostaje na bardzo wysokim poziomie. W Bułgarii w $2012 \mathrm{r}$. sięgnął pułapu 49,3\%, w Rumunii natomiast $41,7 \%$. Wysoki jego poziom odnotowano ponadto na Łotwie (36,6\%), w Grecji (34,6\%), na Węgrzech $(32,4 \%)$ i we Włoszech $(30,4)$. Warto w tym miejscu zaznaczyć, iż są to zarazem państwa, w których wskaźnik ten w ostatnich latach wyraźnie wzrósł. Najniższy jego poziom zanotowano natomiast w państwach skandynawskich, tj. Szwecji $(16,1 \%$ za 2011 r.) i Finlandii (17,2\%), a także w Holandii $(15,0 \%)$, Czechach (15,4\%), Luksemburgu (18,4\%) i Austrii (16,9\% za 2011 r.).

Zagrożenie ubóstwem dotyczy także osób pracujących, co jest jeszcze bardziej niepokojące. Na poziomie UE-28 udział osób, których ekwiwalentne dochody do dyspozycji są poniżej progu zagrożenia ubóstwem, wzrósł z 8,4\% w 2010 do 9,5\% za rok 2012. 
Pracujący zagrożeni ubóstwem (\% populacji pracujących) ${ }^{6}$

\begin{tabular}{||l|c|c|c|c|c|c|c|c||}
\hline \multirow{2}{*}{\multicolumn{1}{|c|}{ Państwo }} & \multicolumn{7}{|c|}{ Rok } \\
\cline { 2 - 9 } & $\mathbf{2 0 0 5}$ & $\mathbf{2 0 0 6}$ & $\mathbf{2 0 0 7}$ & $\mathbf{2 0 0 8}$ & $\mathbf{2 0 0 9}$ & $\mathbf{2 0 1 0}$ & $\mathbf{2 0 1 1}$ & $\mathbf{2 0 1 2}$ \\
\hline UE 28 & - & - & - & - & - & $\mathbf{8 , 4}$ & $\mathbf{8 , 9}$ & $\mathbf{9 , 5}$ \\
\hline Austria & 6,7 & 6,4 & 6,1 & 6,4 & 5,9 & 4,9 & 5,4 & - \\
\hline Belgia & 3,9 & 4,2 & 4,4 & 4,8 & 4,6 & 4,5 & 4,2 & - \\
\hline Bułgaria & - & 5,4 & 5,8 & 7,5 & 7,5 & 7,7 & 8,2 & 7,4 \\
\hline Chorwacja & - & - & - & - & - & 5,9 & 6,5 & - \\
\hline Cypr & 6,5 & 7,2 & 6,3 & $6,3^{\text {b }}$ & 6,8 & 7,3 & 7,3 & 7,9 \\
\hline Czechy & 3,5 & 3,5 & 3,3 & 3,6 & 3,2 & 3,7 & 4,0 & 4,5 \\
\hline Dania & 4,9 & 4,5 & 4,2 & 5,1 & 5,9 & 6,6 & 6,4 & 5,7 \\
\hline Estonia & 7,5 & 7,5 & 7,8 & 7,3 & 8,1 & 6,5 & 7,9 & 8,3 \\
\hline Finlandia & 3,7 & 4,5 & 5,0 & 5,1 & 3,7 & 3,7 & 3,9 & 3,8 \\
\hline Francja & 6,1 & 6,1 & 6,5 & $6,7^{b}$ & 6,6 & 6,2 & 7,6 & 8,0 \\
\hline Grecja & 12,9 & 13,9 & 14,3 & 14,3 & 13,8 & 13,8 & 11,9 & 15,1 \\
\hline Hiszpania & 10,6 & 10,1 & 10,3 & 11,2 & 11,7 & 12,8 & 12,2 & 12,3 \\
\hline Holandia & 5,8 & 4,4 & 4,6 & 4,8 & 5,0 & 5,1 & 5,5 & 4,6 \\
\hline Irlandia & 6,1 & 6,2 & 5,6 & 6,5 & 5,4 & 5,5 & 5,6 & - \\
\hline Litwa & 10,0 & 9,9 & 8,0 & 9,4 & 10,4 & 12,3 & 9,5 & 7,6 \\
\hline Luksemburg & 9,8 & 10,3 & 9,3 & 9,4 & 10,0 & 10,6 & 9,9 & 10,2 \\
\hline Lotwa & 9,0 & 11,2 & 9,7 & 11,0 & 11,2 & 9,7 & $9,4^{\mathrm{b}}$ & 8,8 \\
\hline Malta & 4,1 & 4,1 & 4,5 & 5,0 & 5,7 & 5,7 & 6,0 & 5,7 \\
\hline Niemcy & 4,8 & 5,5 & 7,5 & 7,1 & 6,8 & 7,2 & 7,7 & 7,8 \\
\hline Polska & 13,9 & 12,8 & 11,7 & 11,5 & 11,1 & 11,5 & 11,1 & 10,4 \\
\hline Portugalia & 11,9 & 11,3 & 9,7 & 11,8 & 10,3 & 9,7 & 10,3 & 9,9 \\
\hline Rumunia & - & - & 18,5 & 17,7 & 17,9 & 17,3 & 19,0 & 19,2 \\
\hline Słowacja & 8,9 & 6,3 & 4,9 & 5,8 & 5,2 & 5,7 & 6,3 & 6,2 \\
\hline Słowenia & 4,6 & 4,8 & 4,7 & 5,1 & 4,8 & 5,3 & 6,0 & 6,5 \\
\hline Szwecja & 5,5 & 7,4 & 6,5 & 6,8 & 6,9 & 6,5 & 6,9 & - \\
\hline Węgry & 8,8 & 6,8 & 5,8 & 5,8 & 6,2 & 5,3 & 6,1 & 5,3 \\
\hline Wielka Brytania & 8,3 & 7,8 & 8,0 & 8,5 & 6,7 & 6,8 & 7,9 & - \\
\hline Włochy & 8,8 & 9,6 & 9,8 & 8,9 & 10,3 & 9,4 & 10,7 & $12,2^{\text {t }}$ \\
\hline
\end{tabular}

$-=$ brak danych;

$\mathrm{b}=$ przerwa $\mathrm{w}$ serii danych;

$\mathrm{t}=$ tymczasowy.

Źródło: Eurostat, http://epp.eurostat.ec.europa.eu/portal/page/portal/income_social_inclusion_living_conditions/data/main_tables, dostęp 29.10.2013.

Najwyższe wartości wskaźnik ten przyjmuje dla Rumunii, w której blisko 20\% pracujących jest zagrożonych ubóstwem. W Grecji ekwiwalentne dochody do dyspozycji

${ }^{6}$ Udział osób pracujących posiadających ekwiwalentne dochody do dyspozycji poniżej progu zagrożenia ubóstwem, który jest ustalony na poziomie $60 \%$ krajowej mediany dochodu do dyspozycji po transferach socjalnych. 
poniżej progu zagrożenia ubóstwem otrzymuje $15,1 \%$ pracujących. Wysokie wartości wskaźnik ten osiągnął także dla Hiszpanii (12,3\%), Włoch (12,2) Polski (10,4\%), a także dla Luksemburga $(10,2)$. Najmniej pracujących zagrożonych ubóstwem zanotowano w Finlandii (3,8\%), Belgii (4,2\% za 2011 r.), Czechach (4,5\%) i Holandii (4,6\%).

$$
* * *
$$

Unia Europejska należy do najbogatszych regionów świata. Jest też oczywistym, iż jej wewnętrzne zróżnicowanie w poziomie życia mieszkańców jest zdecydowanie mniejsze niż w ujęciu ponadkontynentalnym. Mimo tej konstatacji zróżnicowanie to na poziomie międzypaństwowym jest nadal wyraźne i co więcej, w niektórych wymiarach ulega pogłębieniu. Przyglądając się zmianom, jakie zaszły w poszczególnych latach, można tę sytuację wiązać z nieodległym kryzysem finansowym. Wysokie zróżnicowanie dochodowe występuje w państwach $\mathrm{z}$ najkrótszym stażem członkowstwa w UE - Bułgarii i Rumunii oraz tych borykających się z poważnymi problemami związanymi z kryzysem (Grecja, Hiszpania, Portugalia, także Łotwa). Osobom 60+ najlepiej żyje się w Szwecji, Niemczech oraz Holandii. Najgorzej w tej klasyfikacji wypadła Polska. Niepokojącym jest zanotowany wzrost wartości wskaźnika zagrożenia ubóstwem lub wykluczeniem społecznym. Największy w podobnym przedziale czasowym zanotowano w Grecji, Irlandii, Włoszech, Hiszpanii, na Litwie, w Bułgarii, na Węgrzech i Cyprze. Ponadto w kilku państwach wskaźnik ten pozostaje na bardzo wysokim poziomie (Bułgaria, Rumunia, Łotwa, Grecja, Węgry, Włochy). Co więcej są to zarazem państwa, w których wskaźnik ten w ostatnich latach wyraźnie wzrósł. Najniższy jego poziom zanotowano natomiast w państwach skandynawskich, tj. Holandii, Szwecji i Finlandii, a także w Czechach, Luksemburgu i Austrii. Bardzo niepokojącym jest, iż zagrożenie ubóstwem dotyka także osób pracujących. W Rumunii jest to co piąta osoba pracująca. Wysokie wartości wskaźnik ten przyjmuje także dla Grecji Hiszpanii, Włoch, Polski, a także dla Luksemburga. Najmniej pracujących zagrożonych ubóstwem zanotowano w Finlandii, Belgii, Czechach i Holandii.

\section{Bibliografia}

Eurostat news release, 21/2012 - 8 February 2012 .

Eurostat news release, 171/2012 - 3 December 2012.

Food and Agriculture Organization of the United Nations (2013), The State of Food Insecurity in the World. The multiple dimensions of food security, Rome.

HelpAge International (2013), Global AgeWatch Index 2013. Insight Report.

Eurofund, http://www.eurofound.europa.eu/surveys/smt/3eqls/index.EF.php?locale=EN, dostęp 23.10.2013.

Eurostat (2013a), http://epp.eurostat.ec.europa.eu/portal/page/portal/income_social_inclusion_living_conditions/introduction, dostęp 23.10.2013.

Eurostat (2013b), http://epp.eurostat.ec.europa.eu/statistics_explained/index.php/Glossary:EU_statistics_on_income_and_living_conditions_(EU-SILC)/pl, dostęp 23.10.2013. 
Eurostat (2013c), http://epp.eurostat.ec.europa.eu/portal/page/portal/income_social_inclusion_living_conditions/data/main_tables, dostęp 29.10.2013.

Eurostat (2013d), http://epp.eurostat.ec.europa.eu/portal/page/portal/income_social_inclusion_living_conditions/data/main_tables, dostęp 29.10.2013.

\section{Streszczenie}

W artykule przedstawiono problematykę zróżnicowania poziomu życia mieszkańców Unii Europejskiej. W pierwszej części zaprezentowano zagadnienia teoretyczne dotyczące mierzenia różnych wymiarów jakości życia w ramach badań prowadzonych przez Unię Europejską (EU-SILC, EQLS) oraz międzynarodową organizację HelpAge Intermational (GAWI). W drugiej zasadniczej części artykułu analizie poddano wybrane obiektywne i subiektywne wskaźniki: poziomu ekwiwalentnych dochodów do dyspozycji (współczynnik Giniego), sytuacji gospodarstw domowych w poszczególnych państwach, a także jakości życia mieszkańców w wieku 60 lat i więcej. Trzecia część artykułu przedstawia analizę oceny poziomu zagrożenia ubóstwem i wykluczeniem społecznym w Unii Europejskiej.

\section{Summary}

\section{Variations in the living standards of European Union citizens}

The paper presents the issue of the varied standards of living in the European Union. The first part of the paper discusses theoretical matters concerning the measurement of various dimensions of the quality of life examined by the European Union (EU-SILC, EQLS) and an international organization HelpAge International (GAWI). The second, fundamental part of the paper analyzes selected objective and subjective indicators, such as equivalent levels of disposable income (Gini coefficient), the situation of households in different countries as well as the quality of life of senior citizens (aged 60 plus). The third part of the paper is an analysis of the assessment of the threat of poverty and social exclusion in the European Union. 